\title{
PENGARUH INTENSITAS BERMAIN GAME TERHADAP TINGKAT KOGNITIF (KECERDASAN LOGIKA-MATEMATIKA) USIA 8-9 TAHUN
}

\author{
Kukuh Pambuka Putra \\ Kukuh.pambuka@outlook.com \\ Fakultas Kedokteran Dan Ilmu Kesehatan \\ Universitas Kristen Satya Wacana \\ Theresia Pratiwi Elingsetyo Sanubari \\ Pratiwi.elingsetyo@staff.uksw.edu \\ Fakultas Kedokteran Dan Ilmu Kesehatan \\ Universitas Kristen Satya Wacana \\ Theresita Febriane Manggena \\ 462013023@student.uksw.edu \\ Fakultas Kedokteran Dan Ilmu Kesehatan \\ Universitas Kristen Satya Wacana
}

\begin{abstract}
The advance of technology could ease the people for work. One kind of this is gadget. Gadget is not only used by adult, yet the children too to access the game. The game also used to bolster the aspects of growth, either is cognitive growth. Cognitive growth is required to improve the brain power. The purpose of this research is to find out the effect of the intensity of playing games to cognitive level (LogicalMathematical Intelegence) for the children aged 8-9 years Logical-Mathematical Intelegence may be valued or represented by the numeracy skills. This research utilize quantitative and descriptive method by using several instrument such as math test and questionnaire. Analysis Data Technique, performed by using the normality test of kolmagrov-smirnov, shapiro-wilk and mann-whitney test. This research done in The Christian Primary School of Satya Wacana to 603 rd graders pupils. The research to the respondent result that 30 pupils who playing games with average of time 4,9 hours a day and 4,5 hours a week have score of numeracy skills $\leq 70$. While theother 30 pupils who playing games with verage of time 2,8 hours a day and 2,2 hours a week have score of numeracy skills $>70$. This data shows that the score $<70$ owned by the pupils who play the games longer. Duration of playing games $<3$ hours or $>3$ hours a day have a significant impact to cognitive level Likewise, duration of playing games $<21$ hours or >21 hours a week have a significant impact to cognitive level.
\end{abstract}

Key words : Playing Game, Cognitive (Logical-Mathematical Intelegence), brain ability.

\section{PENDAHULUAN}

Perkembangan teknologi yang
semakin canggih dapat memudahkan
pekerjaan manusia. Salah satu teknologi yang
sangat popular adalah gadget. Gadget
contohnya laptop atau komputer, tablet PC dan
smartphone (Octaviana, Pertiwi, Purnama,
Hapsery, \& Yoshinta, 2011). Saat ini gadget
tidak hanya digunakan oleh kalangan orang dewasa, namun juga banyak digunakan oleh anak - anak (Warisyah, 2015).

Berdasarkan survey oleh The Asian Parent Insight (2014) yang dilakukan di lima negara termasuk Indonesia, melibatkan anakanak yang menggunakan gadget. Dari $98 \%$ anak-anak pengguna gadget diantaranya $67 \%$ menggunakan gadget milik orang tua, $18 \%$ gadget milik saudara atau keluarga dan $14 \%$ 
milik sendiri. Hasil survey juga mengungkapkan sebagian besar responden memiliki Gadget jenis Handphone (telepon genggam). Handphone selain sebagai alat komunikasi, anak-anak menggunakan untuk mengakses game (Fajrin, 2015).

Bermain game dapat berdampak positif dan negatif bagi anak. Salah satu dampak positif dari bermain game adalah meningkatkan kemampuan menalar atau logika. Dalam game terdapat permasalahan yang harus dicari jalan keluarnya untuk mencapai tahapan/tujuan tertentu, sehingga diperlukan kemampuan berpikir dan bernalar untuk dapat menyelesaikan setiap permasalahan dalam game. Kegemaran bermain game membuat anak dapat mengasah otak untuk memecahkan permasalahan sehingga kemampuan menalarnya terus mengalami perkembangan (Agata, 2015). Namun, Anak yang bermain game secara berlebihan akan menimbulkan dampak negatif bagi perkembangan kognitif. Dampak negatif game lebih dirasakan jika terjadi kecanduan bermain game. Apabila game dimainkan secara berlebihan anak-anak tidak dapat mengerjakan tugas yang diberikan sekolah, tidak konsentrasi pada waktu proses pembelajaran, tidur di dalam kelas bahkan sampai bolos sekolah (Dani, Sukidin, \& S, 2014). Anak-anak juga memiliki motivasi belajar menurun seperti malas belajar sehingga dapat mempengaruhi perkembangan kognitif atau kecerdasan anak (Suziedelyte, 2012), terutama pada kecerdasan logika-matematika (berpikir logis, mengenal angka).

Games yang digunakan anak-anak dapat mendukung aspek-aspek perkembangan anak. Salah satu aspek perkembangan adalah perkembangan kognitif (proses berfikir) (Nurvitasari, 2016). Menurut Piaget dalam Yudiasmini, Agung, \& Ujianti, 2014 ada 4 tahap perkembangan kognitif anak: tahap sensorimotor (0-2 tahun), tahap praoperasional (2-7 tahun), tahap operasi konkret (8-11 tahun), tahap operasi formal (11 tahun ke atas). Tahap sensorimotor ditandai dengan tindakan anak berdasarkan yang ada di pikirannya.
Tahap praoperasi mengenal dan menggunakan simbol-simbol untuk menghadirkan suatu benda atau pemikiran, khususnya penggunaan bahasa. Tahap operasi konkret ditandai dengan penalaran yang logis. Tahap operasi formal dicirikan dengan pemikiran abstrak, hipotesis, deduktif, serta induktif (Yudiasmini et al., 2014).

Perkembangan kognitif sangat diperlukan untuk meningkatkan kemampuan otak. Misalnya mengelompokkan warna, mengenal bilangan, mengenal bentuk geometri, mengenal ukuran, mengenal konsep ruang, mengenal konsep waktu, mengenal berbagai pola, dan lain-lain. Belajar sambil bermain memberikan kesempatan kepada anak untuk memanipulasi, mengulang-ulang, bereksplorasi, mempraktekan dan mendapatkan bermacam-macam konsep serta pengertian yang tidak terhitung banyaknya. Bermain juga memiliki tujuan yakni memelihara perkembangan atau pertumbuhan anak melalui pendekatan bermain yang kreatif, interaktif dan terintegrasi dengan lingkungan bermain anak. Penekanan dari bermain adalah perkembangan kreativitas sangat individual dan bervariasi antar anak yang satu dengan yang lainnya (Kurniasih, 2013).

Game mempengaruhi kemampuan belajar dan kecerdasan anak secara positif maupun negatif, namun perlu diketahui bagaimana pengaruh intensitas game terhadap tingkat kognitif (kecerdasan logikamatematika) pada anak usia 8-9 tahun. Tujuan penelitian ini adalah untuk mengetahui pengaruh intensitas bermain game terhadap tingkat kognitif (kecerdasan logikamatematika) anak usia 8-9 tahun. Kecerdasan logika-matematika dapat di lihat dari kemampuan berhitung, penalaran atau logika dan pemecahan masalahan.

Manfaat dari penelitian ini untuk memberikan infomasi bagi masyarakat dan pelajar mengenai dampak positif dan negatif dari bermain game terhadap kognitif (kecerdasan logika-matematika). Memberikan atau menjadi masukan bagi para pendidik untuk bekerjasama dengan orang tua dan pihak 
kesehatan seperti perawat komunitas dalam upaya pembinaan pada anak dalam mencegah terjadinya kecanduan dari bermain game.

\section{METODE PENELITIAN}

Metode penelitian yang digunakan dalam penelitian ini adalah kuantitatif deskriptif. Penelitian ini mendeskripsikan pengaruh intensitas dalam bermain game terhadap tingkat kognitif (kecerdasan logika matematika). Populasi pada penelitian ini adalalah siswa-siswi kelas 3 Sekolah Dasar Kristen Satya Wacana Salatiga yang berjumlah 70 anak. Penentuan subyek dalam penelitian ini adalah seluruh populasi (Sugiyono, 2016). Responden yang mengikuti penelitan sebanyak 60 anak karena sebagian siswa-siswi yang tidak hadir (izin) dan juga tidak bersedia menjadi responden.

Kriteria inklusi penelitian ini adalah siswa-siswi Sekolah Dasar Kristen Satya Wacana Salatiga, siswa-siswi usia $8-9$ tahun, durasi bermain game $\leq 3 \mathrm{jam}$ dan $>3$ jam per hari, siswa-siswi bersedia menjadi responden. Kriteria eksklusi adalah siswa-siswi yang tidak hadir saat penelitian dan tidak bersedia

\section{HASIL DAN PEMBAHASAN}

1. Statistik deskriptif

Tabel 1 Distribusi karakteristik responden berdasarkan usia responden, jenis kelamin.

\begin{tabular}{cccc}
\hline Karakteristik & & frekuensi & Persentase \\
\hline \multirow{3}{*}{ Usia } & 8 tahun & 31 & $51,7 \%$ \\
\cline { 2 - 4 } & 9 tahun & 29 & $48,8 \%$ \\
\cline { 2 - 4 } & Jumlah & 60 & $100 \%$ \\
\cline { 2 - 4 } Jenis kelamin & laki-laki & 36 & $60,0 \%$ \\
\cline { 2 - 4 } & Perempuan & 24 & $40,0 \%$ \\
\cline { 2 - 4 } & Jumlah & 60 & $100 \%$
\end{tabular}

Berdasarkan tabel di atas, sebagian besar usia responden yang bermain game 31 $(51.7 \%)$ berusia 8 tahun, sedangkan usia 9 tahun $29(48.8 \%)$. Berdasarkan jenis kelamin sebagian besar responden laki-laki berjumlah $36(60.0 \%)$ dan jenis kelamin perempuan berjumlah $24(40.0 \%)$

2. Uji normalitas

a. Pengelompokkan bermain game dalam satuan jam per hari menjadi responden. Instrumen yang di gunakan berupa kuesioner yang berisi pertanyaan seputar kebiasaan bermain game dan soal tes matematika untuk mengetahui kognitif (kecerdasan logika-matematika). Kecerdasan logika-matematika akan di nilai melalui kemampuan berhitung. Instrumen ini telah melalui pengujian validitas dan reliabilitas. Data dibagi menjadi 2 kategori yaitu $\leq 3$ jam per hari atau atau $>3$ dan $\leq 21$ jam per minggu atau $>21$ jam per minggu. 21 jam per minggu diperoleh dari hasil perkalian jam per hari dan hari per minggu.

Data yang dikumpulkan dianalisa secara statistik berupa uji normalitas dan uji mann-whitney. Uji normalitas menggunakan uji one-sample Kolmogorov-smirnov dan shapiro-wilk untuk mengetahu normalitas data. Analisis statistik menggunakan uji mannwhitney karena data berdistribusi tidak normal. Uji mann-whitney untuk mengetahui perbedaan dari kelompok yang bermain game $\leq 3$ jam jam per hari dan $>3$ jam per hari $(\leq 21$ jam per minggu dan $>21$ jam per minggu). 
Tabel 2 Hasil uji normalitas durasi bermain game jam per hari

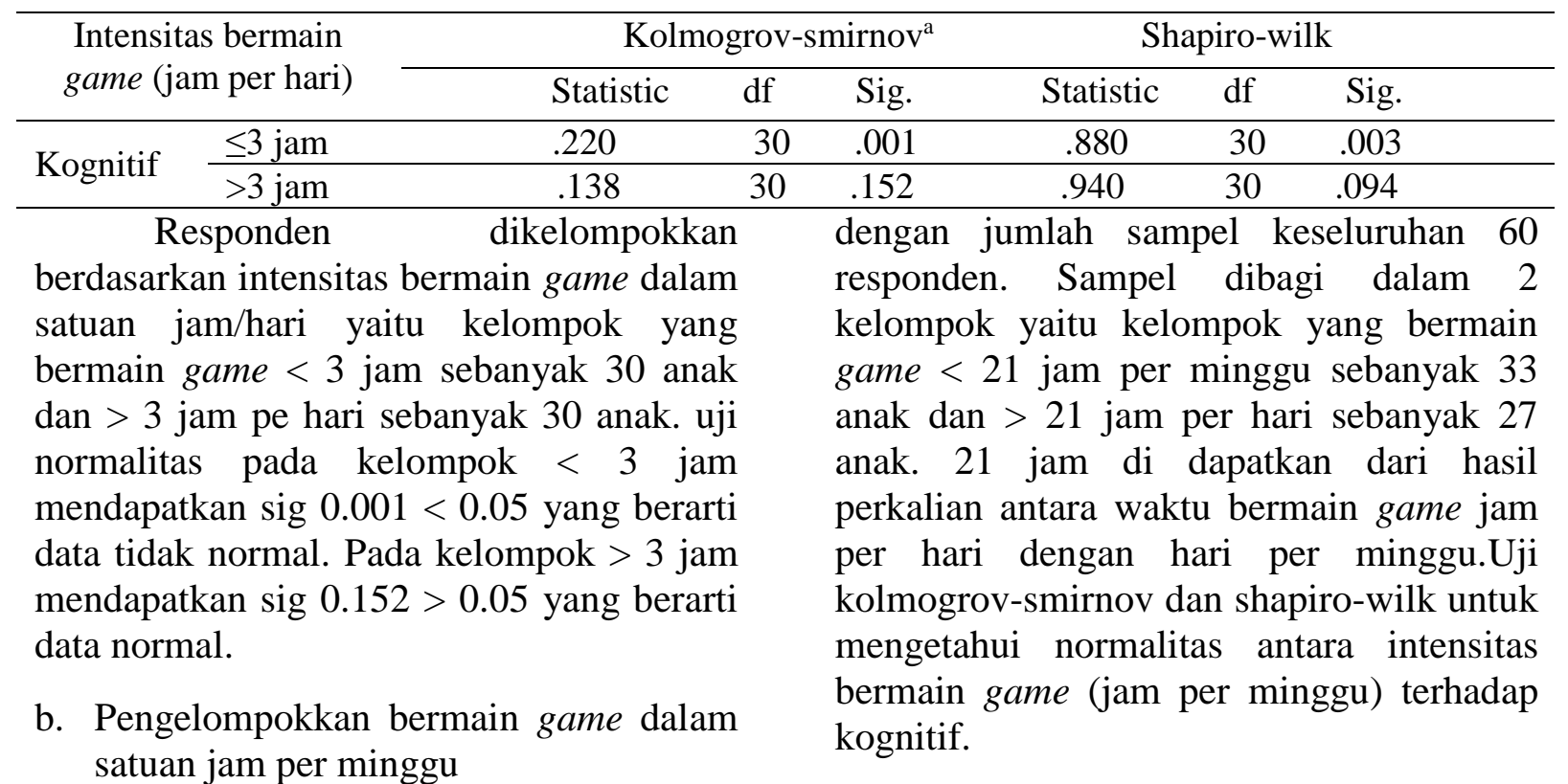

Uji normalitas menggunakan uji kolmogrov-smirnov ${ }^{\text {a }}$ dan shapiro-wilk

Tabel 3 Hasil uji normalitas durasi bermain game jam per minggu

\begin{tabular}{rlcccccc}
\hline \multirow{2}{*}{$\begin{array}{r}\text { Intensitas bermain } \\
\text { game (jam per hari) }\end{array}$} & \multicolumn{3}{c}{ Kolmogrov-smirnov } & \multicolumn{3}{c}{ Shapiro-wilk } \\
\cline { 2 - 8 } & Statistic & df & Sig. & Statistic & df & Sig. \\
\hline \multirow{2}{*}{ Kognitif } & $\leq 21$ jam & .212 & 33 & .001 & .990 & 33 & .005 \\
\cline { 2 - 8 } & $>21$ jam & .149 & 27 & .131 & .928 & 27 & .063 \\
\hline
\end{tabular}

Responden dikelompokkan berdasarkan intensitas bermain game dalam satuan jam/minggu yaitu kelompok yang bermain game < 21 jam sebanyak 33 anak dan > 21 jam pe hari sebanyak 27 anak. uji normalitas

Tabel 4 Hasil nilai kognitif

\begin{tabular}{llll}
\hline & \multicolumn{3}{c}{ Intensitas Bermain Game } \\
\hline & Jumlah & per hari & per minggu \\
\hline Nilai $\leq 70$ & 30 & 4.9 jam & 4.5 jam \\
\hline Nilai $>70$ & 30 & 2.8 jam & 2.2 jam \\
\hline
\end{tabular}

Responden dengan nilai kemampuan berhitung < 70 sebanyak 30 anak dengan rata-rata waktu bermain game 4.9 jam per hari dan 4.5 jam per minggu. Responden dengan nilai kemampuan berhitung > 70 sebanyak 30 anak dengan rata-rata waktu bermain game 2.8 jam per hari dan 2.2 jam per minggu. Data ini menunjukkan bahwa nilai $\leq 70$ cendrung bermain game lama.

\section{Analisa data}

Setelah dilakukakan uji normalitas bahwa data dengan waktu $<3$ jam per hari dan $<21$ jam per minggu menunjukkan tidak normal, maka data di olah menggunakan uji Mann-Whitney.Uji mann- 
whitney digunakan untuk mengetahui perbedaan antara durasi bermain game (jam per hari) dengan kognitif pada siswa-siswi

SD Kristen Satya Wacana tahun 2017.

Tabel 5 Hasil uji mann-whitney antara durasi bermain game jam per hari dan nilai kognitif

\begin{tabular}{lcccc}
\hline Durasi Bermain Game (Jam per Hari) & $\mathrm{N}$ & Mean Rank & Sum of Ranks \\
\hline \multirow{2}{*}{ kognitif } & $\leq 3$ jam & 30 & 36.55 & 1096.50 \\
\cline { 2 - 5 } & $>3$ jam & 30 & 24.45 & 733.50 \\
\hline Total & 60 & & \\
\hline
\end{tabular}

Tabel di atas menunjukkan Mean Rank atau rata-rata peringkat tiap kelompok yaitu nilai kemampuan berhitung untuk kelompok durasi bermain game $\leq 3$ jam per hari Test statistic ${ }^{\mathrm{a}}$ adalah 36.55 dan kelompok dengan durasi bermain game > 3 jam per hari adalah 24.45 .

\begin{tabular}{ll}
\hline & Kognitif \\
\hline Mann-Whitney U & 268.500 \\
Wilcoxon W & 733.500 \\
Z & -2.697 \\
Asymp. Sig. )2-tailed) & .007
\end{tabular}

Tabel di atas menunjukkan hasil signifikan mann-whitney didapat sig.(2tailed) $0.007<0.05$ artinya terdapat perbedaan signifikan durasi bermain game $<3$ jam per hari dan > 3 jam per hari terhadap kognitif pada siswa-siswi SD Kristen Satya Wacana Salatiga. Uji mann-

whitney digunakan untuk mengetahui perbedaan antara durasi bermain game (jam per minggu) dengan kognitif pada siswasiswi SD Kristen Satya Wacana tahun 2017. 21 jam di dapatkan dari hasil perkalian antara waktu bermain game jam per hari dengan hari per minggu

Tabel 6 Hasil uji mann-whitney antara durasi bermain game jam per minggu dan nilai kognitif

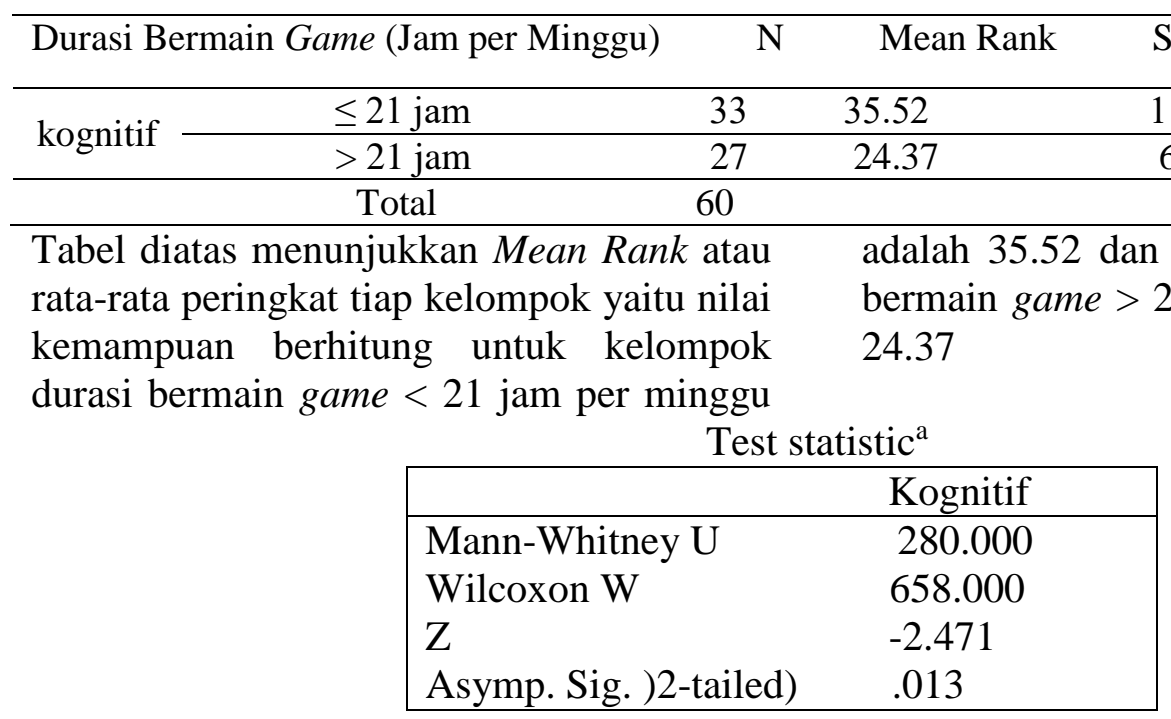

Tabel di atas menunjukan hasil signifikan mann-whitney didapat sig.(2tailed) $0.013<0.05$ artinya terdapat perbedaan signifikan antara durasi bermain game jam per minggu terhadap kognitf siswa-siswi di SD Kristen Satya Wacana Salatiga 


\section{PEMBAHASAN}

Bermain game merupakan sebuah kegiatan yang sering dilakukan anak-anak sebagai sarana untuk mengisi waktu luang. Usia responden pada penelitian ini adalah usia 8 tahun $31(51,7 \%)$ dan usia 9 tahun 29 (48,8\%). Usia 8-9 tahun merupakan usia sekolah dasar. Rentang usia anak pada tahap usia sekolah dasar berkisar 6-12 tahun disebut sebagai masa pertengahan dalam periode anak-anak. Periode ini dianggap sebagai masa perkembangan anak karena masa ini akan terus berlanjut hingga tahap perkembangan selanjutnya (Wong, 2002). Penelitian ini menemukan bahwa anak usia 8-9 tahun gemar memainkan game. Terbukti dengan masih terdapat anak usia ini bermain game $>3$ jam dan $>21$ jam per minggu, sehingga dikatakan anak-anak mengalami kecanduan bermain game. Penelitian Griffiths dalam broto tahun 2006 bahwa usia mulai 7 tahun anak-anak mulai tertarik pada game dan beberapa dari mereka sudah megalami kecanduan bermain game, terbukti dengan waktu bermain game 4 jam per hari dan 30 jam per minggu (Broto, 2006). Pada penelitian ini menemukan anak-anak usia 8-9 tahun mengakses game menggunakan handphone. Anak-anak tersebut kecanduan bermain game yang terdapat dalam handphone sehingga berdampak negatif pada perilaku belajar seperti konsentrasi dalam mengikuti kegiatan belajar. Penelitian Azolla Silviani tahun 2013 mengemukakan bahwa 50\% siswa-siswi SD kelas dua sampai kelas enam kecanduaan menggunakan smartphone untuk mengakses game sehingga hal ini dapat berdampak negatif terhadap perilaku belajar siswa (Silviani, 2013).

Dalam penelitian ini di dapatkan jumlah siswa laki-laki $36(60 \%)$, sedangkan jenis kelamin perempuan 24 (40\%). Jumlah siswa laki-laki bermain game cenderung lebih banyak bermain game dibandingkan siswa perempuan. Penelitian Maria Nuhan pada tahun 2016 menyatakan bahwa siswa laki-laki bermain game cendrung lebih banyak dari pada siswa perempuan (Nuhan, 2016). Seorang peneliti dari Stanford university school of medicine, Allan Reiss menemukan bahwa terdapat perbedaan pengaruh pada otak laki-laki dan pada perempuan ketika bermain game. penelitian ini melihat reaksi yang berbeda pada otak laki dan perempuan saat bermain game. Saat bermain game laki-laki lebih agresif saat bermain game dan termotivasi untuk menyelesaikan tantangan atau level yang terdapat dalam game, sehingga hal ini mengaktifkan bagian-bagian otak yang berfungsi mengendalikan emosi dan rasa takut jika tidak dapat memenangkan game serta kemampuan kognitif (Reiss, 2008). Otak anak laki-laki cenderung lebih mengenali simbol, bentuk-bentuk abstraksi, diagram, gambar, untuk itu laki-laki lebih unggul dalam bidang matematika dan fisika terutama ketika subjek itu diajarkan didepan kelas (Gurian, 2006)

Dalam penelitian ini, didapatkan bahwa Responden yang memiliki nilai kemampuan berhitung dengan skor $\leq 70$ memiliki intensitas bermain game 4,9 jam per hari atau 4,5 jam perminggu. Responden yang memiliki nilai kemampuan berhitung dengan skor $>70$ memiliki intensitas bermain game 2,8 jam per hari atau 2,2 jam per minggu. Responden yang memiliki nilai kemampuan berhitung $>70$ cenderung bermain game tidak lama atau $\leq 3$ jam sehingga dapat dikatakan bahwa bermain game dengan durasi $\leq 3$ jam dapat membantu mengembangkan kemampuan kognitif seperti menghitung, memecahkan masalah dan logika. Menurut penelitian Ali Saghir bahwa anak-anak yang bermain game 1 atau 2 jam dapat megembangkan kemampuan kognitif seperti menghitung, mengenal banyak bentuk, memecahkan masalah dan logika (Saghir, 2016). Nilai kemampuan berhitung $\leq 70$ cenderung bermain game lama atau > 3 jam. Anakanak yang bermain game lama atau > 3 jam 
dikatakan bahwa anak tersebut mengalami kecanduan sehingga berpengaruh pada perilaku akademisnya seperti malas mengikuti pelajaran dan tidak mengerjakan tugas. Penelitian Riska Wulan dani pada tahun 2014 menyatakan bahwa siswa yang kecanduan bermain game mengalami berbagai masalah terutama pada perilaku akademis. Perilaku akademis seperti tidak mengerjakan tugas, malas mengikuti kegiatan belajar dan tidak adanya konsentrasi pada diri siswa (Dani et al., 2014)Bermain game $\leq 3$ jam dan $>3$ jam per hari dapat mempengaruhi otak sehingga berdampak pada kerja dan fungsi otak itu sendiri yang berkaitan dengan kognitif atau kecerdasan. Penelitian Marc Palaus dkk menyatakan bermain video game dapat mengubah cara kerja otak dan strukturnya. Otak yang bermain game dapat mempertahankan perhatian atau konsentrasi serta meningkatkan kemampuan kognitif atau kecerdasan. Namun jika bermain game dengan berlebihan dapat menimbulkan dampak negatif terhadap otak (Palaus, Marron, Viejo, \& Redolar-Ripoll1, 2017).

Hasil uji perbedaan durasi bermain game dan kognitif menunjukan bahwa bermain game $\leq 3$ jam per hari, $>3$ jam per hari dan $\leq 21$ jam per minggu, $>21$ jam per minggu memiliki pengaruh terhadap tingkat kognitif seperti kemampuan belajar atau intelegensi, kemampuan menghitung, logika berpikir. Hal ini dapat mempengaruhi perkembangan dan fungsi otak yang bertanggung jawab terhadap kecerdasan (intelektual) dan kognitif. Penelitian Paturel menyatakan bahwa bermain video game dapat mempengaruhi perkembangan otak pada lobus frontal. Lobus frontal bertanggung jawab terhadap kognitif meliputi penalaran atau logika, perilaku, pemecahan masalah dan sebagainya (Paturel, 2014).

\section{SIMPULAN}

Dari penelitian ini dapat disimpulkan bahwa terdapat perbedaan intensitas bermain game dengan durasi $\leq$ 3jam dan $>3$ jam jam per hari, durasi $\leq 21$ jam per minggu dan $>21$ jam per minggu terhadap tingkat kognitif (kecerdasan logika-matematika). Bermain game dengan durasi sebentar dapat berdampak positif terhadap kognitif atau kecerdasan. Bermain game dengan durasi yang lama dan dilakukan setiap hari maka dapat berdampak negatif terhadap kognitif atau kecerdasan. Bermain game dapat mengembangkan kemampuan otak yang berkitan dengan kognitif atau kecerdasan logika-matematika seperti kemampuan menghitung, logika berpikir dan pemecahan masalah. Game dapat membantu anak belajar jika bermainnya dapat dikontrol atau dibatasi dengan durasi $\leq 3$ jam per hari.

\section{DAFTAR PUSTAKA}

Agata, L. (2015). pengaruh kegemaran bermain game terhadap kemampuan menalar siswa di sd n premulung no 94 surakarta tahun 2014/2015. Fakultas Keguruan Dan Ilmu Pendidikan Universitas Muhammadiyah Surakarta, xv(94), 119.

Broto, R. A. (2006). Dampak Video game pada Anak Perlu Diwaspadai. kolumnis: Rab A. Broto.

Dani, R. wulan, Sukidin, \& S, R. N. (2014). Fenomena Kecanduan Game Online pada Siswa ( Studi Kasus pada Siswa SMK Negeri 2 Jember ). Program Studi Pendidikan Ekonomi Jurusan Pendidikan IPS, Fakultas Keguruan Dan Ilmu Pendidikan, Universitas Jember (UNEJ) Abstrak.

Fajrin, O. R. (2015). Hubungan Tingkat Penggunaan Teknologi Mobile Gadget dan Eksistensi Permainan Tradisional pada Anak Sekolah Dasar. Jurnal Idea Societa, 2(6), 1-33.

Gurian, M. (2006). the wonder of boys, cara membesarkan laki laki menjadi pria sejati. jakarta: serambi ilmu semesta. 
Kurniasih, N. (2013). Penggunaan Alat Permainan Edukatif (APE) Terhadap Perkembangan Kognitif Anka Usia Dini Di Kelompok Bermain Mahadul Qur'an. Jurnal Ilmiah.

Nuhan, M. Y. G. (2016). hubungan intensitas bermain game online dengan prestasi belajar siswa kelas 1v sekolah dasar negeri jarakan kabupaten bantul yogyakarta. Pendidikan Guru Sekolah Dasar, 6(5), 494-501.

Nurvitasari, M. D. (2016). Penerapan Aspek Perkembangan Anak Usia Dini Dalam Media Macca (Balok Susun Interaktif). Pendidikan Anak Usia Dini, 95-104.

Octaviana, F. A., Pertiwi, T. J., Purnama, G. L., Hapsery, Y., \& Yoshinta, A. (2011). Faktor Pengaruh Gadget Terhadap Kecerdasan Motorik Siswa SD Melalui Regresi Logistik Ordinal, $1-5$.

Palaus, M., Marron, E., Viejo, R., \& Redolar-Ripoll1, D. (2017). Neural Basis of Video Gaming: A Systematic Review. Cognitive NeuroLab, Faculty of Health Sciences, Universitat Oberta de Catalunya, Barcelona, Spain.

Paturel. (2014). Game Theory: How do video games affect the developing brains of children and teens? $L W W$ Journal, 10(3), 32-36.

Reiss, A. (2008). Video games activate reward regions of brain in men more than women, Stanford study finds. Stanford University School of Medicine. Retrieved from http://med.stanford.edu/news/allnews/2008/02/video-games-activatereward-regions-of-brain-in-men-morethan-women-stanford-study-finds.html

Saghir, A. (2016). Influence of Video
Games in Learning. Journal of Emerging Trends in Computing and Information, 7(8), 338-342.

Silviani, A. (2013). Penggunaan smartphone pada kalangan anak usia sekolah dasar (studi di Sekolah Dasar Negeri Ungaran 01 Yogyakarta). yogyakarta: Universitas gajah Mada. Retrieved from http://etd.repository.ugm.ac.id/index.p hp?mod=penelitian_detail\&sub=Peneli tianDetail\&act=view \&typ $=$ html\&buku _id=66602\&obyek_id=4

Sugiyono. (2016). Metode Penelitian Kuantitatif, Kualitatif, dan $R \& D$. Bandung: Alfabeta.

Suziedelyte, A. (2012). Can video games affect children' $\mathrm{s}$ cognitive and noncognitive skills? Australian School of Business Building, 4, 1-34.

Warisyah, Y. (2015). Pentingnya "pendampingan dialogis" orang tua dalam penggunaan gadget pada anak usia dinia. Prosiding Seminar Nasional Pendidikan "Inovasi Pembelajaran Untuk Pendidikan Berkemajuan, 130138.

Wong, D. . (2002). buku ajar keperawatan pediatrik volume 1 edisi 6. Jakarta: buku kedokteran EGC.

Yudiasmini, N. komang evi, Agung, A. . G., \& Ujianti, P. rahayu. (2014). penerapan model pembelajaran kooperatif tipe teams games tournament (TGT) berbantuan media puzzle dalam meningkatkan perkembangan kognitif. E-Journal $P G-P A U D$ Universitas Pendidikan Ganesha Jurusan PENDIDIKAN ANAK USIA DINI, 2(1). 